\title{
ANALISIS TINGKAT KESEHATAN BANK PT. BANK PERKREDITAN RAKYAT JORONG KAMPUNG TANGAH PARIAMAN CABANG PADANG
}

\author{
Junika Sukma, Doni Marlius \\ Akademi Keuangan dan Perbankan "Pembangunan" \\ junikasukma24@gmail.com
}

\begin{abstract}
The purpose of this study was to determine how the Bank's Soundness at PT. Bank Perkreditan Rakyat JKT-Pariaman, Padang Branch. The research method used is a qualitative and quantitative data analysis method. The type of data used is secondary data obtained from the publication report of the Financial Services Authority and the People's Credit Bank JKT-Pariaman Padang Branch for the period 2017-2018. Analysis of the level of financial health of banks using the CAMEL method (Capital, Asset, Management, Earning, Liquidity). The results showed that the level of financial health of BPR JKT-Pariaman Padang Branch in 2017-2018 showed a healthy category, where CAR 2017-2018 was above the BI standard of 8\% which means healthy, and ROA owned in a healthy condition while the LDR Ratio of PT. BPR-JKT Pariaman Padang Branch is not in the healthy category in 2017-2018 banks cannot keep the LDR below $94.75 \%$.
\end{abstract}

Keywords : Bank soundness, CAMEL (CAR, KAP, NPM, ROA, BOPO, and LDR)

\section{PENDAHULUAN}

Kemajuan suatu Negara salah satunya di pengaruhi oleh perkembangan perekonomiannya, perbankan sangat berperan penting di dalamnya, dimana perbankan merupakan tentang bank dan segala sesuatu yang menyangkut didalamnya baik dalam menjalankan kegiatan usaha ataupun kelembagaaan. Bank adalah badan usaha yang menghimpun dana dari masyarakat dalam bentuk simpanan dan menyalurkannya ke masyarakat dalam bentuk kredit dan/atau bentukbentuk lainnya dalam rangka meningkatkan taraf hidup rakyat banyak(UndangUndang Nomor 10 Tahun 1998). Kesehatan dari bank haruslah sangat diperhatikan oleh bank. Kesehatan bank merupakan kemampuan dari suatu bank baik dalam melakukan kegiatan operasional dengan baik dan mampu memenuhi kewajiban sesuai peraturan perbankan yang berlaku. Jika suatu bank bisa menjalankan fungsi intermediasi dengan baik, bisa menjaga kepercayaan dari masyarakat, dapat membantu kelancaran lalu lintas pembayaran, serta kebijakan moneter nya dapat terlaksana yang merupakan fungsi- fungsi dari bank, apabila bank dapat menjalankan nya maka bank dapat dikatakan sehat.(Saputra, 2016)

Berdasarkan Surat Edaran Bank Indonesia No.6/23/DPNP tanggal 31 Mei 2004, penilaian tingkat kesehatan bank yang terdiri dari penilaian kualitatif atas berbagai aspek yang berpengaruh terhadap kondisi atau kinerja suatu bank melalui penilaian aspek permodalan, kualitas asset, manajemen, rentabilitas, likuiditas dan sensitivitas terhadap resiko pasar. Penggolongan tingkat kesehatan bank 
dibagi dalam empat kagetori yaitu : sehat, cukup sehat, kurang sehat, dan tidak sehat.

Penilaian kuantitatif dan berbagai aspek lainnya juga sangat berpengaruh pada tingkat kinerja suatu bank, begitu juga dengan penilaian kualitatif yang mana terhadap faktor- faktor yaitu capital, asset quality, earning, management dan liquidity yang disingkat CAMEL. Pada analisa CAMEL kriteria yang ditentukan oleh Bank Indonesia adalah seberapa besar persentase kinerja keuangan yang memenuhi persyaratan bank tersebut untuk dinyatakan sehat dan tidak merugikan pihak- pihak yang berkepentingan.

Bank Indonesia yang merupakan bank sentral ikut dalam penyehatan bank yang ada di Indonesia, karena Bank Indonesia bertugas mengatur dan mengawasi jalannya kegiatan operasional bank. Oleh karena itu Bank Indonesia menetapkan peraturan yang harus dilaksanakan oleh perbankan yang ada di Indonesia, termasuk Bank Perkreditan Rakyat. Pada saat sekarang ini Bank Perkreditan Rakyat (BPR) juga memiliki pasar tersendiri bagi masyarakat, khususnya masyarakat daerah. (Imamah, 2012) Pada umumnya masyarakat yang mempunyai usaha kecil menengah cenderung memilih Bank Perkreditan Rakyat (BPR) sebagai tempat untuk mengembangkan usahanya dengan meminjam uang dengan bunga kredit kecil dan prosedur peminjamannya mudah dengan didukung oleh manajemen BPR itu sendiri. Bagi masyarakat yang menyimpan dananya berupa tabungan pada Bank Perkreditan Rakyat (BPR) maka Bank Perkreditan Rakyat memberikan fasilitas dengan menjemput tabungan langsung ke rumah nasabah, tanpa perlu nasabah pergi ke bank, yang gunanya agar nasabah merasa puas dan nyaman, jika nasabah puas maka nasabah akan royal untuk menyimpan dananya pada Bank Perkreditan Rakyat, yang membedakan Bank Perkreditan Rakyat (BPR) dengan Bank Umum ialah pada Bank Perkreditan Rakyat (BPR) tidak ada giro, yang mana pada Bank Perkreditan Rakyat (BPR) dilarang menerima simpanan giro, kegiatan valas, dan perasurasian.

Untuk mendorong pertumbuhan Bank Perkreditan Rakyat maka Otoritas Jasa Keuangan (OJK) berupaya melakukan transformasi dengan memperhatikan kualitas Bank Perkreditan Rayat dan meningkatkan nya, salah satunya melalui kerja sama dan berkonsolidasi dengan bank umum. Bank Perkreditan Rakyat yang harus sehat dan dapat dipercaya oleh masyarakat kerena bagian dari sistem perbankan, yang bertujuan agar bisa menggerakkan dan membangun perekonomian daerah secara sehat dan menyeluruh. Hadirnya Bank Perkreditan Rakyat ini dapat membantu masyarakat yang memiliki usaha terutama usaha mikro kecil dan menengah.

Kesehatan BPR merupakan salah satu hal yang sangat penting dimana Bank Perkreditan Rakyat merupakan bagian dari perbankan yang harus sehat karena Bank Perkreditan Rakyat mendorong pertumbuhan perekonomian di suatu wilayah, sedangkan bagi penilaian konsumen atau masyarakat terhadap tingkat perkembangan suatu bank yang mana menjadi pengaruh besar bagi masyarakat untuk bergabung pada bank tersebut. Jika bank tersebut dalam keadaan sehat maka ini menjadi daya pikat bagi masyarakat untuk bergabung pada bank tersebut. Bank yang sehat dijadikan sebagai patokan oleh masyarakat bahwa bank 
tersebut mampu berkembang dan dapat bersaing, serta mampu bertahan pada masanya.

Penilaian tingkat kesehatan bank itu sendiri dapat menggunakan metode CAMEL, yang mana kompenen nya yaitu permodalan, aktiva, management, rentabilitas dan likuiditas. Apabila suatu bank mengalami masalah dalam salah satu faktor tersebut maka bank dapat mengalami kesulitan.

PT. Bank Perkreditan Rakyat Jorong Kampuang Tangah Pariaman cabang Padang atau biasa disingkat dengan PT. BPR- JKT Pariaman cabang Padang ini terletak di Jl. Adinegoro, Lubuk Buaya, Kota Padang Sumatera Barat. BPR ini berperan memberikan kontribusi aktif bagi keberhasilan pelaksanaan pembangunan khususnya di bidang penyediaan modal bagi masyarakat. Salah satu indikator yang di gunakan untuk menilai keberhasilan atau kegagalan BPR dalam mencapai tujuan tersebut adalah laporan kinerja keuangan perusahaan yang telah dicapai. Penilaian atau analisa kinerja keuangan suatu BPR sangat penting begitu juga bagi semua jenis usaha yang bertujuan untuk mencapai laba, serta untuk peningkatan dan perkembangan PT. BPR- JKT Pariaman Cabang Padang untuk masa yang akan datang.

Laporan mengenai data keuangan PT. BPR-JKT Pariaman cabang Padang dalam kurun waktu 2017 dan 2018, dapat dilihat pada tabel berikut ini :

Tabel 1

Data Keuangan PT. BPR- JKT Pariaman Cabang Padang Tahun 2017- 2018

(Rp. 000)

\begin{tabular}{ccc}
\hline Indikator & $\mathbf{2 0 1 7}$ & $\mathbf{2 0 1 8}$ \\
\hline Modal & 3.848 .100 & 4.820 .800 \\
ATMR & $26.728 .770,1$ & $29.158 .918,2$ \\
Laba sebelum pajak & 1.353 .020 & 1.349 .399 \\
Total Asset & 41.466 .863 & 43.921 .715 \\
Kredit yang diberikan & 33.667 .703 & 37.375 .950 \\
Dana Pihak Ketiga & 22.616 .153 & 25.044 .593 \\
APYD & $635.306,75$ & 593.640 \\
Jumlah Asset Produktif & 33.370 .143 & 37.062 .383
\end{tabular}

Sumber: Laporan Keuangan PT. BPR-JKT Pariaman

Tabel 1 mengidentifikasi terdapat fluktasi atau ketidak tepatan rasio, karena adanya peningkatan dan penurunan dari nilai keuangan seperti modal, ATMR, laba sebelum pajak, total asset, kredit yang diberikan, dana pihak ketiga, APYD, dan jumlah asset produktif dari PT. BPR-JKT Pariaman cabang Padang.

CAR berdasarkan standar Bank Indonesia minimal 8\% tergolong sehat, yang mana CAR terdiri dari modal dibagi dengan ATMR. Modal pada tahun 2017 di BPR-JKT Pariaman cabang Padang sebesar Rp 3.848.100.000 dan tahun 2018 
modal sebesar Rp. 4.820.800.000 yang mana modal mengalami kenaikan dari tahun 2017 ke 2018 sebesar Rp 972.700.000. Untuk ATMR pada tahun 2017 sebesar Rp. 267.287.701.000 dan tahun 2018 sebesar 291.589.182.000 yang mana mengalami peningkatan sebesar Rp. 24.301.481.000. Untuk Laba sebelum pajak pada tahun 2017 sebesar Rp. 1.353.020.000 dan pada tahun 2018 sebesar Rp. 1.349.399.000 dan disini terjadi penurunan pada laba sebelum pajak sebesar Rp. 3.621.000. Untuk total asset pada tahun 2017 sebesar Rp. 41.466.863.000 dan 2018 sebesar Rp. 43.921.715.000, mengalami peningkatan sebesar Rp. 2.454.852.000. Pada kredit yang diberikan tahun 2017 senilai $R p 33.607 .703 .000$ dan tahun 2018 senilai Rp 37.375.950.000 maka mengalami peningkatan sebesar Rp 3.768.247.000 Untuk dana pihak ketiga di tahun 2017 sebesar Rp 22.616.153.000 dan 2018 sebesar Rp 25.044.593.000 maka mengalami peningkatan sebesar Rp 2.428.440.000 Sedangkan pada APYD tahun 2017 sebesar Rp 63.530.675.000 dan pada tahun 2018 sebesar Rp 593.640.000 maka APYD mengalami penurunan sebesar Rp 4.166.675.000 dari tahun 2017 ke 2018. Jumlah asset produktif di tahun 2017 senilai Rp 33.370.143.000 dan 2018 senilai Rp 37.062.383.000 maka mengalami peningkatan sebesar Rp 3.692.240.000.

Secara keseluruhan data keuangan pada PT. BPR-JKT Pariaman Cabang Padang mengalami peningkatan, namun pada laba sebelum pajak dan APYD mengalami penurunan. Melihat kenyataan diatas, maka sangat penting bagi bank untuk menganalisis tingkat kesehatan bank untuk kelangsungan operasional bank dalam meghadapi persaingan di dunia perbankan. Maka dari itu diperlukannya metode CAMEL yaitu Capital (Permodalan) Quality (Kualitas Asset), Management (Manajemen), Earning (Rentabilitas), Liquidity (Likuiditas). Yang mana untuk menganalisis tingkat kesehatan bank untuk mempertahankan kelangsungan operasional suatu bank dalam mengahadapi persaingan pada zaman sekarang ini.

Berdasarkan uraian tersebut maka penulis tertarik untuk menganalis dan menuangkan dalam bentuk tugas akhir yang berjudul "Analisis Tingkat Kesehatan Bank Pada PT. Bank Perkreditan Rakyat Jorong Kampung Tangah Pariaman Cabang Padang".

Berdasarkan uraian latar belakang diatas, maka rumusan masalah dalam penelitian ini adalah "Bagaimana tingkat kesehatan bank pada PT. Bank Perkreditan Rakyat Jorong Kampuang Tangah Pariaman Cabang Padang dengan menggunakan metode CAMEL selama periode tahun 2017 dan 2018 berada dalam kondisi sehat?"

Penelitian ini bertujuan untuk mengetahui bagaimana tingkat kesehatan bank pada PT. Bank Perkreditan Rakyat Jorong Kampuang Tangah Pariaman Cabang Padang dengan menggunakan metode CAMEL selama periode tahun 2017 dan 2018 berada dalam kondisi sehat.

Adapun manfaat penelitian ini, penulis berharap dapat bermanfaat antara lain: a. Bagi perusahaan sebagai tolok ukur bagi manajemen PT. Bank Perkreditan Rakyat Jorong Kampuang Tangah Pariaman Cabang Padang untuk menilai apakah pengelolaan bank sudah dilaksanakan dengan baik sesuai dengan peraturan yang telah ditetapkan dan sebagai acuan untuk menentukan strategi usaha dan kebijakan dimasa akan datang. b. Bagi penulis untuk memenuhi salah 
satu syarat untuk mencapai gelar Diploma III Keuangan dan Perbankan di AKBP Padang. c. Sebagai referensi bagi penelitian sejenis.

\section{METODE PENELITIAN}

Dalam pengumpulan data dan bahan untuk melakukan penelitian ini, penulis menggunakan metode dengan dua cara sebagai berikut : a. Peninjauan Langsung Ke Objek yaitu Peninjauan langsung ke objek penelitian dipilih untuk meneliti hasil data primer. Penelitian langsung ke lapangan ini akan dapat membantu penulis untuk melengkapi data yang diperlukan. Adapun cara riset lapangan ini adalah dengan mewawancarai pihak-pihak yang berkepentingan dalam hal ini adalah perusahaan atau instansi yang terkait. b. Studi Kepustakaan (Library Research) yaitu Penelitian ini dilakukan dengan cara mempelajari bukubuku, makalah-makalah, artikel-artikel, bacaan laporan-laporan dan publikasi yang berhubungan dengan objek penelitian.

\section{HASIL DAN PEMBAHASAN}

\section{Permodalan (Capital)}

Menurut (Jacob, 2013) Keberhasilan suatu bank bukan hanya terletak pada jumlah modal yang dimilikinya melainkan di dasarkan kepada bagaimana bank tersebut mempergunakan modalnya untuk menarik sebanyak mungkin dana / simpanan masyarakat yang kemudian nantinya akan di salurkan kembali kepada masyarakat yang membutuhkannya sehingga memberntuk pendapatan bagi bank tersebut.

Rasio ini digunakan untuk mengukur sejauh mana penurunan yang terjadi dalam total aktiva yang bisa ditutupi oleh modal yang tersedia. Penilaian terhadap pemodalan PT. BPR-JKT Pariaman Cabang Padang menggunakan rasio CAR yang merupakan perbandingan antara modal dengan aktiva tertimbang menurut resiko. Dapat diketahui pada tabel dibawah ini:

\section{Tabel 2}

CAR PT. BPR-JKT Pariaman Cabang Padang tahun 2017-2018

\begin{tabular}{ccccc}
\hline & \multicolumn{2}{c}{$\mathbf{2 0 1 7}$} & \multicolumn{2}{c}{$\mathbf{2 0 1 8}$} \\
\cline { 2 - 5 } Keterangan & $\begin{array}{c}\text { Jumlah } \\
\text { (Ribuan Rp.) }\end{array}$ & $\begin{array}{c}\text { Peningkata } \\
\mathbf{n} \\
(\boldsymbol{\%})\end{array}$ & $\begin{array}{c}\text { Jumlah } \\
\text { (Ribuan Rp.) }\end{array}$ & $\begin{array}{c}\text { Peningkata } \\
\mathbf{n} \\
(\boldsymbol{\%})\end{array}$ \\
\hline a. Jumlah modal & 3.848 .100 & - & 4.820 .800 & $25,3 \%$ \\
b. Jumlah ATMR & $26.728 .770,1$ & - & $29.158 .918,2$ & $9.1 \%$ \\
CAR= a/b $\times 100 \%$ & $14 \%$ & \multicolumn{2}{c}{$16 \%$} & \\
\hline
\end{tabular}

Sumber : Data Olahan

Perhitungan nilai kredit (NK) rasio CAR

$$
\begin{aligned}
& N K=\frac{\text { Rasio }}{0,1 \%}+1 \\
& N K 2017=\frac{14 \%}{0,1 \%}+1=141 \%
\end{aligned}
$$




$$
N K 2018=\frac{16 \%}{0,1 \%}+1=161 \%
$$

Dari tabel 2 diatas dapat dilihat bahwa resiko kecukupan modal (CAR) mengalami kenaikan sebesar 2\%, pada tahun 2017 sebesar 14\% dan pada tahun 2018 sebesar 16\% dikarenakan terjadinya peningkatan modal. Yang mana peningkatan ATMR 9,1\% sedangkan untuk CAR tahun 2017-2018 lebih besar dari $8 \%$ berarti dikatakan SEHAT dalam menyediakan pemodalannya untuk menghadapi resiko-resiko yang mungkin timbul .

2. Kualitas Aktiva Produktif (Assets Quality)

Penilaian KAP yang dimiliki dapat diukur dengan 2 cara yaitu :

a. Rasio KAP/ APYD terhadap Aktiva Produktif

Rasio KAP/ APYD terhadap Aktiva Produktif adalah penjumlahan aktiva produktif yang tergolong non lancar setelah dikalikan bobotnya. Rasio ini digunakan untuk mengukur tingkat kemungkinan diterimanya kembali dana yang ditanamkan. Semakin kecil rasio KAP, maka semakin besar tingkat kemungkinan diterimanya kembali dana yang ditanamkan. APYD menggambarkan Aktiva Produktif yang kurang lancar, diragukan atau macet.

Tabel 3

Laporan Kolektibilitas Aktiva Produktif PT. BPR-JKT Pariaman Cabang Padang Tahun 2017

\begin{tabular}{lrrc}
\hline \multicolumn{1}{c}{ Komponen } & $\begin{array}{c}\text { Nominal } \\
\text { (Ribuan Rp.) }\end{array}$ & $\begin{array}{c}\text { Bobot } \\
(\boldsymbol{\%})\end{array}$ & $\begin{array}{c}\text { Aktiva yang } \\
\text { diklasifikasikan } \\
\text { ( Ribuan Rp.) }\end{array}$ \\
\hline A. Aktiva Produktif yang & & & \\
$\begin{array}{l}\text { Diklasifikasikan (APYD) } \\
\text { · Lancar }\end{array}$ & 39.279 .264 & $0 \%$ & 0 \\
- Kurang Lancar & 97.613 & $50 \%$ & $48.806,5$ \\
· Diragukan & 151.463 & $75 \%$ & $113.597,25$ \\
- Macet & 472.903 & $100 \%$ & 472.903 \\
Jumlah APYD & & & $\mathbf{6 3 5 . 3 0 6 , 7 5}$ \\
\hline B. Aktiva Produktif (AP) & & & \\
- Kredit yang Diberikan & 33.667 .703 & & \\
· Penempatan pada Bank Lain & 6.333 .540 & & $\mathbf{4 0 . 0 0 1 . 2 4 3}$ \\
Jumlah Aktiva Produktif & & & \\
\hline
\end{tabular}

Sumber: Data Olahan 
Tabel 4

Laporan Kolektibilitas Aktiva Produktif

PT. BPR-JKT Pariaman Cabang Padang Tahun 2018

\begin{tabular}{|c|c|c|c|}
\hline Komponen & $\begin{array}{c}\text { Nominal } \\
\text { (Ribuan Rp.) }\end{array}$ & $\begin{array}{c}\text { Bobot } \\
(\%)\end{array}$ & $\begin{array}{c}\text { Aktiva yang } \\
\text { diklasifikasikan } \\
\text { (Ribuan Rp.) }\end{array}$ \\
\hline \multicolumn{4}{|l|}{ A. Aktiva Produktif yang } \\
\hline \multicolumn{4}{|l|}{ Diklasifikasikan (APYD) } \\
\hline - Lancar & 40.963 .576 & $0 \%$ & 0 \\
\hline - Kurang Lancar & 437.910 & $50 \%$ & 218.955 \\
\hline - Diragukan & 0 & $75 \%$ & 0 \\
\hline Macet & 374.685 & $100 \%$ & 374.685 \\
\hline Jumlah APYD & & & 593.640 \\
\hline \multicolumn{4}{|l|}{ B. Aktiva Produktif (AP) } \\
\hline Kredit yang Diberikan & 37.375 .950 & & \\
\hline Penempatan pada Bank Lain & & & \\
\hline Jumlah AP & 4.420 .221 & & \\
\hline
\end{tabular}

Sumber: Data Olahan

Perhitungan Rasio KAP PT. BPR-JKT Pariaman Cabang Padang adalah sebagai berikut:

$\mathrm{KAP}=\frac{\text { Jumlah Aktiva Produktif yang Diklasifikasikan }}{\text { Jumlah Aktiva Produktif }} \times 100 \%$

KAP $2017=\frac{635.306,75}{40.001 .243} \times 100 \%=1,6 \%$

KAP $2018=\frac{593.640}{41.796 .171} \times 100 \%=1,4 \%$

Perhitungan nilai kredit $(\mathrm{NK})$ rasio KAP :

NK $2017=\frac{22,5 \%-1.6 \%}{0,15 \%}=139($ maksimum 100$)$

NK $2018=\frac{22,5 \%-1,4 \%}{0,15 \%}=141($ maksimum 100)

BPR-JKT Pariaman Cabang Padang selama periode 2017-2018 mampu menjaga rasio KAP dibawah 10,35\% sehingga berdasarkan kriteria penilaian rasio KAP BPR-JKT Pariaman Cabang Padang dapat dikategorikan dalam kelompok SEHAT.

b. Rasio PPAP

PPAP yaitu penyisihan penghapusan aktiva produktif yang dibentuk guna menutup risiko kemungkinan kerugian. Semakin besar PPAP maka modal bank akan semakin kecil karena besarnya PPAP ini dicadangkan dari modal. Berikut hasil perhitungan rasio PPAP pada BPRJKT Pariaman Cabang Padang tahun 2017-2018: 
Tabel 5

Laporan Kolektibilitas Aktiva Produktif

PT. BPR-JKT Pariaman Cabang Padang Tahun 2017 (Rp. 000)

\begin{tabular}{lrrc}
\hline Komponen & $\begin{array}{c}\text { Nominal } \\
\text { (Ribuan Rp.) }\end{array}$ & $\begin{array}{c}\text { Bobot } \\
(\boldsymbol{\%})\end{array}$ & $\begin{array}{c}\text { Aktiva yang } \\
\text { diklasifikasikan } \\
\text { (Ribuan Rp.) }\end{array}$ \\
\hline PPAP & & & $\mathbf{3 4 . 4 2 4}$ \\
\hline PPAPWD & 39.279 .264 & $0,5 \%$ & $196.396,32$ \\
- Lancar & 97.613 & $10 \%$ & $9.761,3$ \\
- Kurang lancar & 151.463 & $50 \%$ & $75.731,5$ \\
- Diragukan & 472.903 & $100 \%$ & 472.903 \\
- Macet & & & $\mathbf{7 5 4 . 7 9 2 , 1 2}$ \\
\hline Jumlah PPAPWD & & & \\
\hline
\end{tabular}

Sumber : Data Olahan

Tabel 6

Laporan Kolektibilitas Aktiva Produktif

PT. BPR-JKT Pariaman Cabang Padang Tahun 2018

(Rp. 000)

\begin{tabular}{lrcc}
\hline Komponen & $\begin{array}{c}\text { Nominal } \\
\text { (Ribuan Rp.) }\end{array}$ & $\begin{array}{c}\text { Bobot } \\
(\boldsymbol{\%})\end{array}$ & $\begin{array}{c}\text { Aktiva yang } \\
\text { diklasifikasikan } \\
\text { (Ribuan Rp.) }\end{array}$ \\
\hline PPAP & & & $\mathbf{7 6 . 9 2 5}$ \\
\hline PPAPWD & & & \\
- Lancar & 40.963 .476 & $0,5 \%$ & $204.817,88$ \\
- Kurang lancar & 437.910 & $10 \%$ & 43.791 \\
- Diragukan & 0 & $50 \%$ & 0 \\
- Macet & 374.685 & $100 \%$ & 374.685 \\
Jumlah PPAPWD & & & $\mathbf{6 2 3 . 2 9 3 , 8 8}$ \\
\hline
\end{tabular}

Sumber : Data Diolah

Perhitungan Rasio PPAP :

Rasio PPAP $=\frac{\text { PPAP }}{\text { PPAPWD }} \times 100$

Rasio PPAP $2017=\frac{34.424}{754.792,12} \times 100 \%=4,6 \%$

Rasio PPAP $2018=\frac{76.295}{623.293,88} \times 100 \%=12,3 \%$

Perhitungan nilai kredit (NK) PPAP :

Nilai Kredit (NK) $2017=\frac{4,6 \%}{1 \%}=4,6$ 
Nilai Kredit (NK) $2018=\frac{12,3 \%}{1 \%}=12.3$

BPR-JKT Pariaman Cabang Padang selama periode 2017-2018 tidak mampu menjaga rasio PPAP sebesar $81 \%$ sehingga berdasarkan kriteria penilaian rasio PPAP BPR-JKT Pariaman Cabang Padang dapat dikategorikan dalam kelompok TIDAK SEHAT.

3. Manajemen (Management)

Aspek manajemen dapat diproyeksikan dengan pengukuran rasio yang menggambarkan tingkat keuntungan (laba) secara keseluruhan yang diperoleh bank dibandingkan dengan pendapatan yang diterima dari kegiatan operasionalnya. Penilaian aspek manajemen dapat dilakukan dengan menggunakan perhitungan rasio NPM. Perhitungannya dapat dilihat dari tabel berikut ini :

Tabel 7

Perhitungan Faktor Manajemen

PT. BPR JKT-Pariaman Cabang Padang

Tahun 2017-2018

(Rp.000)

\begin{tabular}{lcc}
\hline \multirow{2}{*}{ Komponen } & \multicolumn{2}{c}{ Tahun } \\
\cline { 2 - 3 } Laba Bersih & 1.119 .585 & $\mathbf{2 0 1 8}$ \\
\hline Pendapatan Operasional & 5.324 .292 & 5.636 .787
\end{tabular}

Sumber : Laporan Keuangan PT. BPR JKT- Pariaman Cabang Padang

Perhitungan rasio NPM sebagai berikut :

$$
\begin{aligned}
& N P M=\frac{\text { Laba Bersih }}{\text { Pendapatan Operasional }} \times 100 \% \\
& N P M 2017=\frac{1.119 .585}{5.324 .292} \times 100 \%=21 \% \\
& N P M 2018=\frac{503.999}{1.775 .842} \times 100 \%=19.7 \%
\end{aligned}
$$

Berdasarkan tabel 7, NPM dapat di katakan sehat yaitu besar dari $5 \%$. Walaupun mengalami penurunan, tetapi NPM BPR JKT- Pariaman Cabang Padang masih dalam kategori sehat.

4. Rentabilitas (Earning)

Perhitungan rentabilitas dengan menggunakan dua rasio yaitu Return on Asset (ROA) merupakan perbandingan laba sebelum pajak dengan rata-rata total aktiva, dan Rasio Biaya Operasional terhadap Pendapatan Operasional (BOPO) merupakan perbandingan pendapatan operasional. Serta dapat dilihat dari tabel di bawah ini.

Perhitungannya dapat dilihat dari tabel dibawah ini : 
Tabel 8

Perhitungan Faktor Rentabilitas PT. BPR-JKT Pariaman Cabang Padang tahun 2017-2018

(Rp. 000)

\begin{tabular}{lcc}
\hline \multicolumn{1}{c}{ Komponen } & $\mathbf{2 0 1 7}$ & Tahun \\
\hline Laba Sebelum Pajak & 1.353 .020 & $\mathbf{2 0 1 8}$ \\
Total Aktiva & 41.466 .863 & 43.921 .715 \\
Beban Operasional & 4.004 .360 & 4.351 .505 \\
Pendapatan Operasional & 5.324 .292 & 5.636 .787 \\
\hline
\end{tabular}

Sumber : Laporan Keuangan PT. BPR JKT- Pariaman Cabang Padang

1. Perhitungan Rasio ROA

$$
\begin{aligned}
& \text { ROA }=\frac{\text { Laba Sebelum Pajak }}{\text { Total Aktiva }} \times 100 \% \\
& \text { ROA } 2017=\frac{1.353 .020}{41.466 .863} \times 100 \%=3,3 \% \\
& \text { ROA } 2018=\frac{1.349 .399}{43.921 .715} \times 100 \%=3,1 \% \\
& \text { Perhitungan Nilai Kredit (NK) ROA : }
\end{aligned}
$$

$N K 2017=\frac{3,3 \%}{0,015 \%}=220($ maksimum 100$)$

$N K 2018=\frac{3,1 \%}{0,015 \%}=206($ maksimum 100$)$

Berdasarkan hasil perhitungan diatas, BPR-JKT Pariaman Cabang Padang mampu menjaga ROA tetap berada diatas $1,215 \%$ sehingga berdasarkan kriteria penilaian ROA BPR-JKT Pariaman Cabang Padang dapat dikategorikan SEHAT.

2. Perhitungan Rasio BOPO

$$
\begin{aligned}
& \text { BOPO }=\frac{\text { Beban Operasional }}{\text { Pendapatan Operasional }} \times 100 \% \\
& \text { BOPO } 2017=\frac{4.004 .360}{5.324 .292} \times 100 \%=75 \% \\
& \text { BOPO } 2018=\frac{4.351 .505}{5.636 .787} \times 100 \%=77 \%
\end{aligned}
$$

Perhitungan Nilai Kredit (NK) BOPO :

$$
\begin{aligned}
& N K 2017=\frac{100 \%-75 \%}{0,08 \%}=312,5(\text { maksimum } 100) \\
& N K 2018=\frac{100 \%-77 \%}{0,08 \%}=287.5(\text { maksimum } 100)
\end{aligned}
$$


Berdasarkan hasil perhitungan tersebut, BPR-JKT Pariaman Cabang Padang mampu menjaga BOPO tetap berada dibawah 93,52\% sehingga berdasarkan kriteria penilaian BOPO BPR-JKT Pariaman Cabang Padang dapat dikategorikan dalam kelompok SEHAT.

5. Likuiditas (Liquidity)

Likuiditas adalah kemampuan untuk membayar kewajiban finansial jangka pendek tepat pada waktunya yang ditunjukkan oleh besar kecilnya aktiva lancar. Penilaian likuiditas dimaksudkan untuk mengevaluasi kemampuan Bank memelihara tingkat likuiditas yang memadai dan kecukupan manajemen resiko likuiditas.

\section{Tabel 9}

Perhitungan Faktor Likuiditas PT. BPR-JKT Pariaman Cabang Padang Tahun 2017-2018 (Rp. 000)

\begin{tabular}{llcl}
\hline Komponen & Tahun & \\
& 2017 & & 2018 \\
\hline
\end{tabular}

1. Cash Ratio

a. Alat likuid

- Kas

276.498

614.034

- Antar Bank Aktiva

6.333 .540

4.420 .221

Jumlah

6.610.038

5.034.255

b. Hutang Lancar

- Kewajiban segera

46,529

67,085

- Tabungan

10.768 .553

11.526 .493

- Deposito

11.847 .600

13.518 .100

Jumlah

22.662.682

25.111.678

2. Loan To Deposit Ratio

a. Kredit yang diberikan

33.667.703

37.375.950

b. Dana pihak ketiga dan Modal

10.768 .553

11.526 .493

- Tabungan

11.847 .600

13.518 .100

- Deposito

3.848 .100

4.820 .800

- Modal

26.464.253

29.865.393

Jumlah

Sumber: Data diolah

1) Perhitungan $\mathrm{CR}$

$C R=\frac{\text { Alat likuid }}{\text { Hutang Lancar }} \times 100 \%$

CR $2017=\frac{6.610 .038}{22.662 .682} \times 100 \%=29 \%$

CR $2018=\frac{5.034 .255}{25.111 .678} \times 100 \%=20 \%$

Perhitungan nilai kredit (NK) $\mathrm{CR}$

$N K=\frac{\text { Angka rasio }}{0,05 \%} \times 1$ 


$$
\begin{aligned}
& N K 2017=\frac{29 \%}{0,05 \%} \times 1=580 \\
& N K 2018=\frac{20 \%}{0,05 \%} \times 1=400
\end{aligned}
$$

Cash Ratio BPR-JKT Pariaman Cabang Padang pada tahun 2017 sebesar 29\% dan tahun 2018 sebesar 20\% Berdasarkan hasil perhitungan tersebut, BPR-JKT Pariaman Cabang Padang mampu menjaga Cash Ratio tetap berada diatas $4,05 \%$ sehingga berdasarkan kriteria penilaian Cash Ratio BPR JKT-Pariaman Cabang Padang dapat dikategorikan dalam kelompok SEHAT.

2) Perhitungan rasio LDR

$$
\begin{aligned}
& L D R=\frac{\text { Kredit yang diberikan }}{\text { Dana pihak ketiga }+ \text { modal }} \times 100 \% \\
& L D R 2017=\frac{33.667 .703}{26.464 .253} \times 100 \%=127 \% \\
& L D R 2018=\frac{37.375 .950}{29.865 .393} \times 100 \%=125 \% \\
& \text { Perhitungan nilai kredit }(\mathrm{NK}) \mathrm{LDR} \\
& N K=\frac{115 \%-\text { Angka rasio }}{1 \%} \times 4 \\
& N K 2017=\frac{115 \%-127 \%}{1 \%} \times 4=-48(\text { maksimum } 100) \\
& N K 2018=\frac{115 \%-125 \%}{1 \%} \times 4=-40(\text { maksimum } 100)
\end{aligned}
$$

LDR BPR-JKT Pariaman Cabang Padang pada tahun 2017 sebesar $127 \%$ dan tahun 2018 sebesar 125\%. Berdasarkan hasil perhitungan tersebut, BPR-JKT Pariaman Cabang Padang tidak mampu menjaga LDR dibawah 94,75\% sehingga berdasarkan kriteria penilaian LDR BPR-JKT Pariaman Cabang Padang dapat dikategorikan dalam kelompok TIDAK SEHAT.

\section{SIMPULAN}

Berdasarkan hasil analisis pada bab sebelumnya bahwa penelitian yang berjudul "Analisis Tingkat Kesehatan Bank Pada PT. Bank Perkreditan Rakyat (BPR) Jorong Kampuang Tangah Pariaman Cabang Padang" dapat disimpulkan sebagai berikut:

1. Capital (Permodalan) yaitu hasil CAR pada PT. BPR JKT Pariaman Cabang Padang untuk periode 2017-2018 berada dalam kategori sehat. Rasio permodalan yang diperoleh PT. BPR JKT Pariaman Cabang Padang selama tahun 2017-2018 adalah sebesar 14\% dan 16\% artinya masih di atas ketentuan yang ditetapkan Bank Indonesia yaitu $8 \%$.

2. Asset Quality (Kualitas Aktiva Produktif) yaitu KAP yang dimiliki PT. BPR JKT Pariaman Cabang Padang untuk periode 2017-2018 sebesar 1,6\% dan 1,4\%. Rasio PPAP yang diperoleh PT. BPR JKT Pariaman Cabang Padang 
selama tahun 2017-2018 adalah sebesar 4,6\% dan 12,3\% dinyatakan Tidak Sehat,

3. Management (Manajemen) yaitu nilai NPM yang dimiliki PT. BPR JKT Pariaman Cabang Padang digolongkan dalam kategori sehat, karena dapat mencapai labanya. Meskipun terjadi penurunan akan tetapi masih berada diatas standar yang ditetapkan oleh BI yaitu diatas $5 \%$.

4. Earnings (Rentabilitas) yang didasarkan pada ROA dan PT. BPR JKT Pariaman Cabang Padang dikategorikan sehat karena mampu menjaga ROA dengan baik diatas $1,215 \%$. Sedangkan untuk rasio BOPO dalam 2 periode tersebut juga tergolong sehat, karena telah memenuhi kriteria sebagai bank yang sehat dengan rasio kurang dari 93,52\%.

5. Likuidity (Likuiditas) yang didasarkan pada cash ratio (CR) dalam dua tahun terakhir tergolong sehat, meski pada tahun 2018 mengalami penurunan, akan tetapi masih berada diatas standar yang ditetapkan yaitu 4,05\%. Sedangkan untuk rasio LDR periode 2017-2018 berada dalam kategori Tidak Sehat, karena rasio LDR berada diatas $94,75 \%$.

\section{UCAPAN TERIMAKSIH}

Terimakasih penulis sampaikan kepada :

1. Kedua Orang Tua yang senantiasa memberikan dukungan baik secara moril maupun materil.

2. Direktur AKBP beserta prodi AKBP yang telah memberikan kesempatan kepada penulis untuk melakukan penelitian ini.

3. Dosen Pembimbing yang telah memberikan arahan dan bimbingan hingga tugas akhir ini bisa terelesaikan.

4. Pimpinan Cabang PT. BPR-JKT Pariaman Cabang Padang yang telah mengizinkan penulis dalam memperoleh informasi beserta pengambilan data.

5. Semua Pihak yang telah memberikan dukungan dan bantuannya dalam penyelesaian tugas akhir ini.

\section{DAFTAR PUSTAKA}

Badria, M., \& Marlius, D. (2019). Analisis Rasio Likuiditas Pada PT. Bank Perkreditan Rakyat (BPR) Lengayang. Https://Doi.Org/10.31219/Osf.Io/Esvb7

Fitri, H. Y., \& Marlius, D. (2019). Analisis Rasio Likuiditas Pada PT. Bank Perkreditan Rakyat (BPR) Nagari Kasang. Https://Doi.Org/10.31219/Osf.Io/Bcs73

Handayani, M., \& Marlius, D. (2017). Analisis Tingkat Kesehatan PT. BPR Batang Kapas. Https://Doi.Org/10.31227/Osf.Io/Bq48z

Imamah, N. (2012). Analisis Camel Untuk Mengukur Tingkat Kesehatan Bank Pt. Bpr Syariah Al-Mabrur Kabupaten Ponorogo Periode 2004-2008. Profit, 6(2012, June), 70-84.

Jacob, J. K. D. (2013). Analisis Laporan Keuangan Dengan Menggunakan Metode Camel Untuk Menilai Ingkat Kesehatan Perbankan. Jurnal EMBA, 1(1), 691-700. Https://Doi.Org/10.1007/S13398-014-0173-7.2 
Mustika, S., \& Marlius, D. (2019). Analisa Tingkat Kesehatan Keuangan PT. Bank Perkreditan Rakyat (BPR) Batang Palangki. Https://Doi.Org/10.31219/Osf.Io/Wupyh

Paul M. Muchinsky. (2012). Pengertian Bank. Psychology Applied To Work: An Introduction To Industrial And Organizational Psychology, Tenth Edition Paul, 53(9), 1-35. Https://Doi.Org/10.1017/CBO9781107415324.004

Putri, Y. A., \& Marlius, D. (2018). Analisis Tingkat Kesehatan Bank Pada PT. Bank Perkreditan Rakyat (BPR) Jorong Kampuang Tangah Pariaman Cabang Padang. Https://Doi.Org/10.31227/Osf.Io/R98pv

Rahmayeli, D. S., \& Marlius, D. (2017). Analisis Kinerja Keuangan Pada PT. Bank Perkreditan Rakyat (BPR) Batang Kapas Pesisir Selatan. Https://Doi.Org/10.31227/Osf.Io/Sz5db

Saputra, H. (2016). Analisis Tingkat Kesehatan Bank Dengan Menggunakan Rasio Camel (Studi Kasus Pada Bank Rakyat Indonesia (Persero) Tbk). Jurnal, 1-30.

Saraswati, R. A. (2012). Peranan Analisis Laporan Keuangan, Penilaian Prinsip 5c Calon Debitur Dan Pengawasan Kredit Terhadap Efektivitas Pemberian Kredit Pada Pd Bpr Bank Pasar Kabupaten Temanggung. Nominal, Barometer Riset Akuntansi Dan Manajemen, 1(1). Https://Doi.Org/10.21831/Nominal.V1i1.994

Sari, Y. P., \& Marlius, D. (2019). Analisis Rasio Profitabilitas Pada Pt. Bank Negara Indonesia Syariah. Https://Doi.Org/10.31219/Osf.Io/94bwq

Mandasari, J. (2015). Analisis Kinerja Keuangan Dengan Pendekatan Metode Rgec Pada Bank Bumn Periode 2012-2013. 3(2), 363-374 